\title{
Bence Jones Proteins and Light Chains of Immunoglobulins
}

\author{
XV. EFFECT OF CORTICOSTEROIDS ON SYNTHESIS AND EXCRETION \\ OF BENCE JONES PROTEIN
}

\author{
Alan Solomon, Memorial Research Center, University of Tennessee Center \\ for the Health Sciences, Knoxville, Tennessee 37920
}

A B S T RACT The effect of corticosteroids and cytotoxic chemotherapeutic agents on the excretion of Bence Jones protein was determined for periods of 162 mo in 29 patients with multiple myeloma and Bence Jones proteinuria. The amount of protein present in 24-h urine specimens collected before treatment and at frequent intervals during monthly treatment cycles was determined. Striking variations occurred in the amount of Bence Jones protein excretion; these changes were especially evident when $75 \mathrm{mg}$ of prednisone were given daily for 7 days as part of a monthly chemotherapeutic regimen. Within the 7-day period seven patients showed essentially no decrease $(<25 \%)$, whereas 13 and 9 patients had a moderate decrease $(25-75 \%)$ or a marked decrease $(>75 \%)$, respectively, in Bence Jones proteinuria as compared to pre-treatment values. The decrease in excretion of Bence Jones protein during this period was attributed mainly to corticosteroid therapy because of the transient nature of the response in most patients and the lack of such response in three patients when the hormone was omitted. Biosynthetic studies were performed to determine in vitro the effect of corticosteroids on Bence Jones protein synthesis. Plasma cells obtained from the bone marrow of 13 patients were incubated in a growth medium containing ${ }^{14} \mathrm{C}$-labeled lysine and isoleucine and prednisone in concentrations up to $240 \mu \mathrm{g} / \mathrm{ml}$, and the amount of Bence Jones protein synthesized was determined immunochemically. No differences in viability were apparent between untreated and prednisone-treated cells. The type of response exhibited by

This work was presented in part at the 16th International Congress of Hematology, Kyoto, Japan, 7 September 1976, and at the 68th Annual Meeting of the American Association for Cancer Research, Denver, Colorado, 19 May 1977.

Received for publication 19 November 1976 and in revised form 10 August 1977. an individual patient in the percent decrease of Bence Jones protein excreted after 7 days of prednisone treatment was comparable to the percent decrease in newly-synthesized Bence Jones protein secreted by tumor cells when cultured in the presence of prednisone at a concentration of $120 \mu \mathrm{g} / \mathrm{ml}$. The marked differences in the capacity of corticosteroids to affect Bence Jones protein synthesis appear to reflect a biochemical heterogeneity among plasma cell neoplasms.

\section{INTRODUCTION}

The administration of corticosteroids to man results in profound alterations of the cellular and humoral immune system (reviewed in Ref. 1). Cytokinetic and pharmacokinetic studies have provided information on the mechanism of action of glucocorticoid hormones, especially in regard to their role in stabilization of lysosomal membranes and their effect on the distribution and function of thymus-derived (T) lymphocytes (2-4). Corticosteroids also influence the capability of bone marrow-derived (B) lymphocytes to synthesize immunoglobulin. The marked decrease in serum concentration of IgG and, to a lesser extent, IgA that results from methylprednisolone administration has been attributed to accelerated catabolism and to suppression of ongoing antibody synthesis $(5,6)$; however, the mechanism by which corticosteroids suppress immunoglobulin synthesis is not known (7).

Previously, we reported that the intermittent administration of corticosteroids as part of a therapeutic regimen for a patient with multiple myeloma (a B cell neoplasm) resulted in an immediate and marked reduction in Bence Jones proteinuria and, concomitantly, in the excretion of a low molecular weight protein related to the carboxyl-terminal half (constant region) of the Bence Jones protein polypep- 
tide chain (8). This phenomenon was observed in several additional patients, but other types of responses were noted among patients treated in similar fashion. We now report the results of analyses of urine protein excretion before treatment and at daily intervals during treatment in 29 patients with multiple myeloma and Bence Jones proteinuria. These data and those obtained from biosynthetic studies in 13 of our patients have provided evidence that the corticosteroid-associated decrease in Bence Jones protein excretion occurring in certain patients may result from a corticosteroid-induced suppression of Bence Jones protein synthesis.

\section{METHODS}

Clinical data. 29 of our patients with multiple myeloma and Bence Jones proteinuria were included in this study (Table I). The diagnosis of multiple myeloma was established by appropriate clinical and laboratory criteria (9). Identification of myeloma proteins and Bence Jones proteins in serum and urine specimens was established by immunoelectrophoretic analyses employing monospecific antisera to immunoglobulins $G, A, M, D$, and $E$ and to $\kappa$ and $\lambda$ Bence Jones proteins (10). Subclassification of $\kappa$ Bence Jones proteins as $\kappa \mathrm{I}, \kappa \mathrm{II}, \kappa \mathrm{III}$, or $\kappa \mathrm{IV}$ and of $\lambda$ Bence Jones proteins as $\lambda I, \lambda I I / \lambda I I I$, or $\lambda I V$ was determined by immunodiffusion analyses with antisera of known specificity $(11,12){ }^{1}$

The protein concentration of urine specimens was measured by a sulfosalicylic acid turbidity method (8) and that of serum specimens by refractometry. The amount of Bence Jones protein relative to other urinary proteins and the concentration of serum myeloma protein were determined by cellulose acetate electrophoresis and densitometry (10).

Treatment protocols. The chemotherapeutic regimens employed in our patients were part of a Southeastern Cancer Study Group randomized Phase III treatment protocol (No. 343) for multiple myeloma. This protocol was designed to compare the effects of intermittent chemotherapy with the alkylating agent melphalan given in a dose of $8 \mathrm{mg} / \mathrm{m}^{2}$ orally for 4 consecutive days at 28-day intervals vs. the alkylating agent cyclophosphamide (Cytoxan, Mead Johnson Laboratories, Evansville, Ind.) plus the nitrosourea compound 1,3-bis(2-chloroethyl)-1-nitrosourea $(\mathrm{BCNU})^{2}$ given intravenously every 28 days in doses of $400 \mathrm{mg} / \mathrm{m}^{2}$ and $75 \mathrm{mg} / \mathrm{m}^{2}$, respectively. Both regimens included the administration of the corticosteroid prednisone given in a single dose of $75 \mathrm{mg}$ for 7 consecutive days with each 28-day treatment cycle.

Specimen collections. A 24-h urine sample was obtained from each patient before treatment and then daily for at least the first 7-14 days of the first treatment cycle. Inasmuch as all of the patients were hospitalized during the initial course of therapy, daily 24 -h urine samples could be readily collected. Post-treatment 24-h urine samples were also obtained weekly from most of the non-hospitalized patients. All specimens were collected without preservative and were maintained

\footnotetext{
${ }^{1}$ Solomon, A. To be published.

${ }^{2}$ Abbreviations used in this paper: $\mathrm{BCNU}, 1,3-\mathrm{bis}$ (2-chloroethyl)-1-nitrosourea; CTX, cyclophosphamide (Cytoxan); $\mathrm{C}_{\mathrm{L}}{ }^{*}$, carboxyl-terminal-related fragment of Bence Jones protein; $\mathrm{C}_{\mathrm{L}}$, constant domain (carboxyl-terminal region) of the light polypeptide chain; $\mathrm{V}_{\mathrm{L}}$, variant domain (amino-terminal region) of the light polypeptide chain.
}

TABLE I

Patients with Multiple Myeloma and Bence Jones Proteinuria

\begin{tabular}{|c|c|c|c|c|c|}
\hline \multirow[b]{2}{*}{ Patient } & \multirow[b]{2}{*}{ Age/Sex } & \multicolumn{2}{|c|}{ Bence Jones protein } & \multicolumn{2}{|c|}{ Myeloma protein } \\
\hline & & Type & $\begin{array}{l}\text { Amount } \\
\text { excreted }\end{array}$ & Class & $\begin{array}{l}\text { Amount } \\
\text { in serum }\end{array}$ \\
\hline & $y r$ & & $\mathrm{~g} / 24 \mathrm{~h}$ & & g/dl \\
\hline BIV & $61 / F$ & $\lambda I I / I_{I}{ }^{*}$ & 10.2 & IgG & 3.9 \\
\hline BOS & $78 / \mathrm{F}$ & $\lambda \mathrm{II} / \mathrm{III}$ & 3.0 & IgA & 3.4 \\
\hline BRE & $83 / \mathrm{F}$ & $\kappa$ III & 11.0 & IgA & 3.0 \\
\hline BUR & $59 / \mathrm{F}$ & $\kappa \mathrm{I}$ & 7.4 & IgG & 4.8 \\
\hline BURG & $70 / F$ & $\lambda I V$ & 5.3 & IgG & 7.5 \\
\hline CLAR & $76 / \mathrm{M}$ & $\lambda I V$ & 2.6 & IgG & 2.6 \\
\hline CLE & $63 / F$ & $\lambda I V$ & 9.5 & IgA & 1.1 \\
\hline COL & $73 / \mathrm{M}$ & $\kappa \mathrm{III}$ & 45.0 & $-\ddagger$ & - \\
\hline COT & $68 / F$ & $\lambda I V$ & 3.1 & IgG & 3.1 \\
\hline COX & $67 / M$ & $\lambda I I / I I I I$ & 7.3 & IgA & 3.3 \\
\hline COXE & $52 / \mathrm{F}$ & $\lambda \mathbf{I}$ & 2.8 & - & - \\
\hline CRO & $48 / F$ & $\kappa \mathrm{I}$ & 4.8 & - & - \\
\hline DRU & $75 / \mathrm{M}$ & $\kappa I$ & 7.8 & IgG & 6.8 \\
\hline EDW & $53 / F$ & $\kappa \mathbf{I}$ & 8.0 & - & - \\
\hline HAN & $72 / \mathrm{M}$ & $\boldsymbol{\kappa} \mathbf{I}$ & $0.3 \S$ & - & - \\
\hline HUD & $60 / \mathrm{F}$ & $\lambda I$ & 14.6 & - & - \\
\hline HUS & $29 / M$ & $\kappa I$ & 7.0 & IgG & 4.9 \\
\hline KIN & 68/M & $\kappa \mathbf{I}$ & 3.8 & - & - \\
\hline KIR & $46 / \mathrm{F}$ & $\lambda \mathrm{II}$ & 3.4 & - & - \\
\hline LAY & $65 / \mathrm{F}$ & $\kappa \mathrm{II}$ & 2.4 & IgA & 7.9 \\
\hline LEN & $29 / M$ & $\kappa I V$ & 24.0 & - & - \\
\hline LEV & $51 / F$ & $\lambda I I$ & 6.5 & - & - \\
\hline MAS & $60 / \mathrm{F}$ & $\lambda I I / I I I$ & 5.8 & $\operatorname{IgA}$ & 2.4 \\
\hline MAY & $55 / \mathrm{M}$ & $\lambda I$ & 17.8 & IgG & 4.7 \\
\hline $\mathrm{McC}$ & $56 / \mathrm{M}$ & $\kappa I I I$ & 16.2 & - & - \\
\hline OAK & $66 / F$ & $\kappa$ III & 4.9 & IgG & 3.2 \\
\hline PAT & $71 / \mathrm{F}$ & $\kappa \mathrm{II}$ & 7.6 & IgA & 5.3 \\
\hline SHE & $50 / \mathrm{M}$ & $\lambda I$ & 15.0 & - & - \\
\hline WMS & $54 / F$ & $\kappa \mathrm{I}$ & 8.0 & IgA & 4.3 \\
\hline
\end{tabular}

* Assignment of subtype as either a $\lambda$ II- or $\lambda I I I$-chain has not been made.

† No myeloma protein present in serum.

$\S$ Acute renal failure and oliguria.

at $0-4^{\circ} \mathrm{C}$ throughout the $24-\mathrm{h}$ collection period. Subsequently, a sample of each 24-h specimen was frozen and stored at $-20^{\circ} \mathrm{C}$ or $-70^{\circ} \mathrm{C}$. Those patients who were able to collect urine daily over extended periods of time were provided with a kit which included several large polyethylene specimen bottles, funnels, graduated cylinders, polyethylene 20-ml scintillation vials, and adhesive labels. Each patient's family was instructed in the method of collection and measurement of a 24-h urine sample, and was requested to transfer a 15-ml aliquot of the 24-h urine sample to a scintillation vial which was to be labeled with the date and total 24-h volume. The vials were then to be frozen and brought to the clinic biweekly. Blood samples for immunoglobulin analyses were also obtained before each treatment cycle and occasionally at more frequent intervals.

Biosynthetic studies. Samples of bone marrow (1-3 ml) were obtained by aspiration from the posterior iliac crest. The marrow particles were collected by centrifugation at 
$230 \mathrm{~g}$ for $10 \mathrm{~min}$ at $20^{\circ} \mathrm{C}$, and were then washed three times by suspending the particles in Hanks' solution, centrifuging, and decanting the supernate. A final suspension was made in $6 \mathrm{ml}$ of a lysine-isoleucine deficient growth medium (NIH Medium No. 320, kindly supplied by Dr. Richard Asofsky, National Institutes of Health, Bethesda, Md.) containing $5 \mathrm{mg} / \mathrm{ml}$ of $3 \mathrm{X}$ crystallized ovalbumin (ICN Nutritional Biochemical Corp., Cleveland, Ohio). An aliquot of the cell suspension was taken for measurement of cell number and for morphologic studies. The number of cells in suspension ranged from $5 \times 10^{5}$ to $1 \times 10^{6} / \mathrm{ml}$; typically, $>85 \%$ of the cells had morphologic characteristics of plasma cells. Radioactive lysine and isoleucine were added to yield $1 \mu \mathrm{Ci} / \mathrm{ml}$ of L-[U- $\left.{ }^{14} \mathrm{C}\right]$ lysine (sp act $287 \mathrm{mCi} / \mathrm{mmol}$, Amersham/Searle Corp., Arlington Heights, Ill.) and $1 \mu \mathrm{Ci} / \mathrm{ml}$ of $\mathrm{L}-\left[\mathrm{U}^{14} \mathrm{C}\right]$ isoleucine (sp act $330 \mathrm{mCi} / \mathrm{mmol}$, Amersham $/$ Searle) before transferring $1-\mathrm{ml}$ aliquots into sterile $16 \times 125-\mathrm{mm}$ glass screw-top tubes. A suspension of prednisone was prepared by dissolving a 5-mg tablet of Deltasone ${ }^{3}$ (The Upjohn Company, Kalamazoo, Mich.) in $10 \mathrm{ml}$ of sterile, preservative-free saline. For control purposes, $2 \mathrm{ml}$ of Hanks' solution were added to culture tube 1 ; appropriate amounts of prednisone and Hanks' solution were added to culture tubes $2,3,4,5$, and 6 to yield a final prednisone concentration of $15,30,60,120$, and $240 \mu \mathrm{g} / \mathrm{ml}$, respectively. The tubes were placed in a roller drum at $37^{\circ} \mathrm{C}$ for $16-18 \mathrm{~h}$. After incubation, the viability of the cells was determined by their ability to exclude trypan blue dye. The culture fluids were first harvested by centrifugation at $230 \mathrm{~g}$ for $10 \mathrm{~min}$ at $20^{\circ} \mathrm{C}$ and then dialyzed extensively against $0.15 \mathrm{M} \mathrm{NaCl}$ at $4^{\circ} \mathrm{C}$ to remove unincorporated ${ }^{14} \mathrm{C}$-labeled amino acids. Samples in Insta-Gel (Packard Instrument Co., Inc., Downers Grove, Ill.) were assayed for radioactivity in a Packard Tri-Carb liquid scintillation spectrometer.

The molecular and electrophoretic profile of newly-synthesized protein, i.e., ${ }^{14} \mathrm{C}$-labeled protein, in the extracellular culture fluid was compared to that of the patient's isolated Bence Jones protein and myeloma protein by gel filtration analyses utilizing P-100 polyacrylamide columns (Bio-Rad Laboratories, Richmond, Calif.) or Ultrogel AcA34 or AcA54 $5 \%$ polyacrylamide- $4 \%$ agarose columns (LKB Instruments, Inc., Rockville, Md.) and by cellulose acetate or agarose gel electrophoresis under conditions previously described $(8,13)$. The amount of ${ }^{14} \mathrm{C}$-labeled Bence Jones protein contained in each culture fluid was determined by immunoprecipitation. To achieve maximum precipitation of ${ }^{14} \mathrm{C}$-labeled Bence Jones protein, we first determined the amount of unlabeled homologous Bence Jones protein needed as carrier to reach the equivalence point of each homologous anti-Bence Jones protein antiserum. The calculated amount of homologous unlabeled Bence Jones protein and an aliquot of culture fluid sufficient to yield $\sim 5,000 \mathrm{cpm}$ were added to $1 \mathrm{ml}$ of antiserum, the mixture was incubated first at $37^{\circ} \mathrm{C}$ for $1 \mathrm{~h}$ then at $4^{\circ} \mathrm{C}$ for an additional $16 \mathrm{~h}$, and the amount of precipitated ${ }^{14} \mathrm{C}$-labeled protein was determined.

\section{RESULTS}

Urine specimens were obtained for protein analyses before treatment and at regular intervals for periods of

${ }^{3}$ Deltasone 5-mg tablets contain as preservative lactose, sucrose, starch, mineral oil, and calcium stearate (personal communication from The Upjohn Co.). Comparable results in culture were observed with the use of preservative-free prednisone obtained from Steroloids, Inc., Wilton, N.H.
1-62 mo from each of our 29 patients who had multiple myeloma and Bence Jones proteinuria. 24-h urine collections were obtained throughout each treatment cycle in the majority of patients, and in patients WMS, HUS, MAY, and LEV continuous daily urine collections were obtained for periods of $11,19,22$, and $30 \mathrm{mo}$, respectively. These analyses revealed remarkable quantitative changes in Bence Jones proteinuria which, in most cases, were particularly evident after specific forms of therapy.

Such changes are illustrated graphically in Fig. 1 which plots, over 11 mo of the 22-mo period of observation, the total urinary protein excreted daily by patient MAY, a 55-yr-old male with multiple myeloma and Bence Jones proteinuria. During the time in which these determinations were made, marked fluctuations in urinary protein excretion occurred. In general, certain day-to-day fluctuations resulted from incomplete 24-h urine collections, whereas sustained changes in proteinuria could be related directly to progression or remission of disease. With the exception of the second treatment cycle, a marked decrease in proteinuria occurred after initiation of therapy. When prednisone was given for 7 days with each treatment cycle, a more immediate reduction in proteinuria occurred than when the cytotoxic drugs were used alone. The decrease in proteinuria began during the period of corticosteroid therapy, but when prednisone was omitted (because of gastric hemorrhage and duodenal ulcer) the decrease occurred $\sim 1$ wk after treatment had been completed. The reduction in proteinuria associated with cytotoxic chemotherapy was transient, and within 2 wk the urinary protein excretion increased progressively. Because of chemotherapy-induced pancytopenia, treatment ordinarily scheduled at 28-day intervals was deferred, and the resulting increase in proteinuria was associated with other manifestations of disease activity. A marked decrease in urine protein excretion from 18.5 to $9.0 \mathrm{~g} / 24 \mathrm{~h}$ occurred during a 3-wk period of time when the patient was hospitalized for an antrectomy and vagotomy. During this period no cytotoxic chemotherapy or corticosteroids were given; however, the patient received $1,000 \mathrm{ml}$ of packed erythrocytes before surgery and $750 \mathrm{ml}$ after surgery. The decrease in proteinuria occurring at this time as well as the decrease associated with chemotherapy was characterized by a reduction in Bence Jones protein excretion. The transient increase in proteinuria which occurred within the first 2-5 days of some chemotherapy cycles represented an increased excretion of albumin and other serum proteins including the IgG myeloma protein.

Initial effects of chemotherapy on Bence Jones proteinuria. When daily urinary protein excretion was measured in our other patients with multiple myeloma and Bence Jones proteinuria, different pat- 

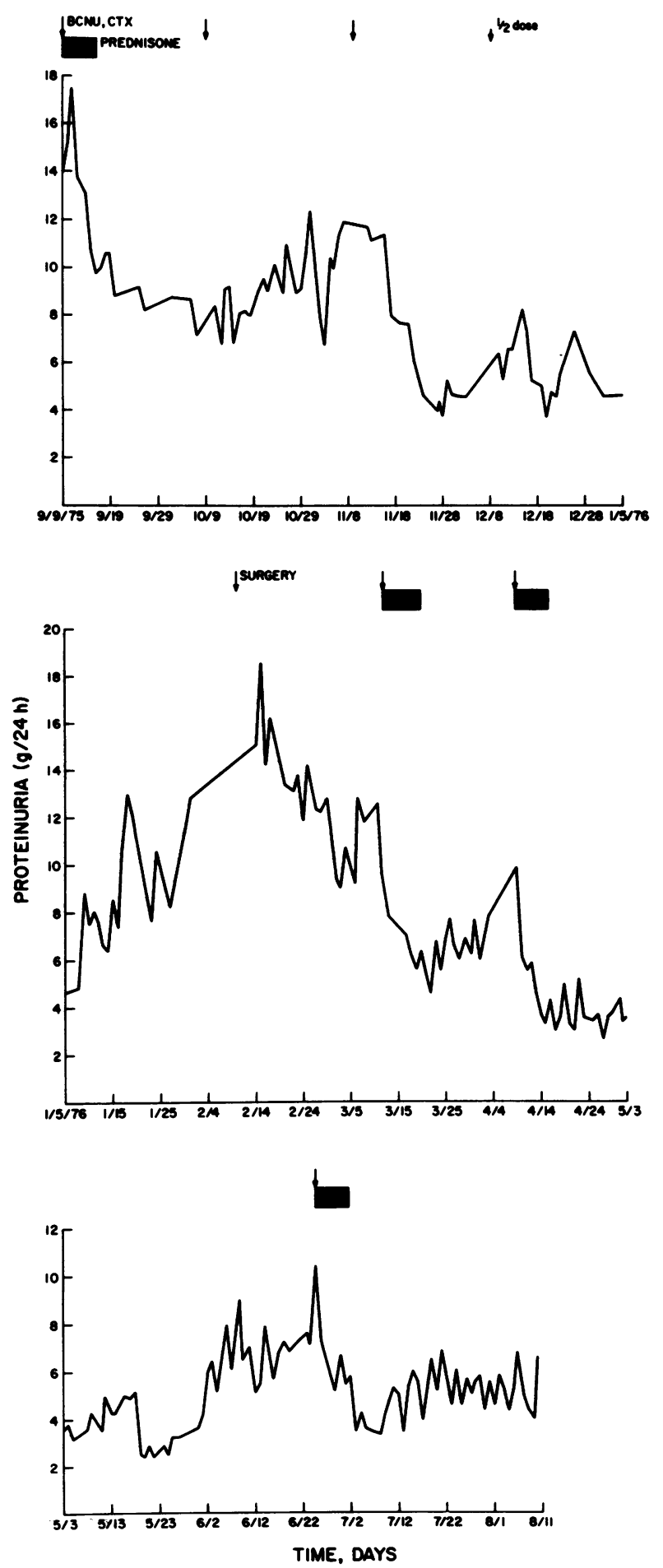

FIGURE 1 Therapy-induced alterations in urinary protein of a patient with multiple myeloma and Bence Jones proteinuria. The amount of daily 24 -h urinary protein excreted during an 11-mo period is presented graphically. The treatment schedules are indicated as follows: solid bar, prednisone, $75 \mathrm{mg}$, given orally for 7 consecutive days; arrow, BCNU, $75 \mathrm{mg} / \mathrm{m}^{2}$, and cyclophosphamide (CTX), $400 \mathrm{mg} / \mathrm{m}^{2}$, given i.v. terns of response were noted after chemotherapy was initiated. These differences were apparent within the first 3-10 days after treatment was begun and were especially evident when corticosteroids were given. In general, three patterns of response were observed during the 7-day period of corticosteroid administration. The types of response, shown graphically for three patients in Fig. 2, included not any or only a minimal $(<25 \%)$, a moderate $(25-75 \%)$, or a marked decrease $(>75 \%)$ in Bence Jones proteinuria as compared with pre-treatment values. The cellulose acetate electropherograms of urine specimens obtained from patients HUD, LEV, and KIN on days 0,3 , and 7 of the treatment cycle indicate that Bence Jones protein excretion decreased considerably in patient HUD, to a lesser extent in patient LEV, and not at all in patient KIN. Each type of response was characteristic for the individual patient, and similar patterns were observed during subsequent treatment cycles. These responses occurred only when corticosteroids were given in association with the cytotoxic drugs and could not be related either to the type of cytotoxic agent(s), to the antigenic type or subtype of Bence Jones protein, or to the extent of disease. The fact that corticosteroids were primarily responsible for the prompt decrease in Bence Jones proteinuria was evidenced by the absence of this effect when corticosteroids were omitted entirely from the treatment regimen (Fig. 1 and Ref. 8, c.f. also Fig. 7). The decrease in Bence Jones proteinuria during the 7 -day period of prednisone treatment was marked in 9 of our 29 patients, moderate in 13, and minimal or absent in 7 (Table II).

Effect of corticosteroids on excretion of Bence Jones protein. The extent of decrease in Bence Jones proteinuria was also dependent on the dose of corticosteroids. As shown in Fig. 3, the decrease in proteinuria in patient CLE was similar when either 75 or $150 \mathrm{mg}$ of prednisone was given for 7 days, but little effect was evident when a 40-mg daily dose was given for the same length of time. Only limited data were available on the effect of prednisone given in a dose of $75 \mathrm{mg}$ daily for periods less than or exceeding 7 days; in two patients a marked decrease in proteinuria occurred after 3 days of treatment, and in two others no further decrease occurred despite continued administrátion of $75 \mathrm{mg}$ of the drug daily for up to 28 days. In some patients it was necessary to administer corticosteroids parenterally; several different agents were employed including dexamethasone given i.m. and methylprednisolone given i.v. The magnitude of response in an individual patient was similar when these agents were used in doses comparable to the orally administered prednisone.

Effect of corticosteroids on synthesis of Bence Jones protein. The marked differences in urinary protein excretion associated with corticosteroid therapy among 


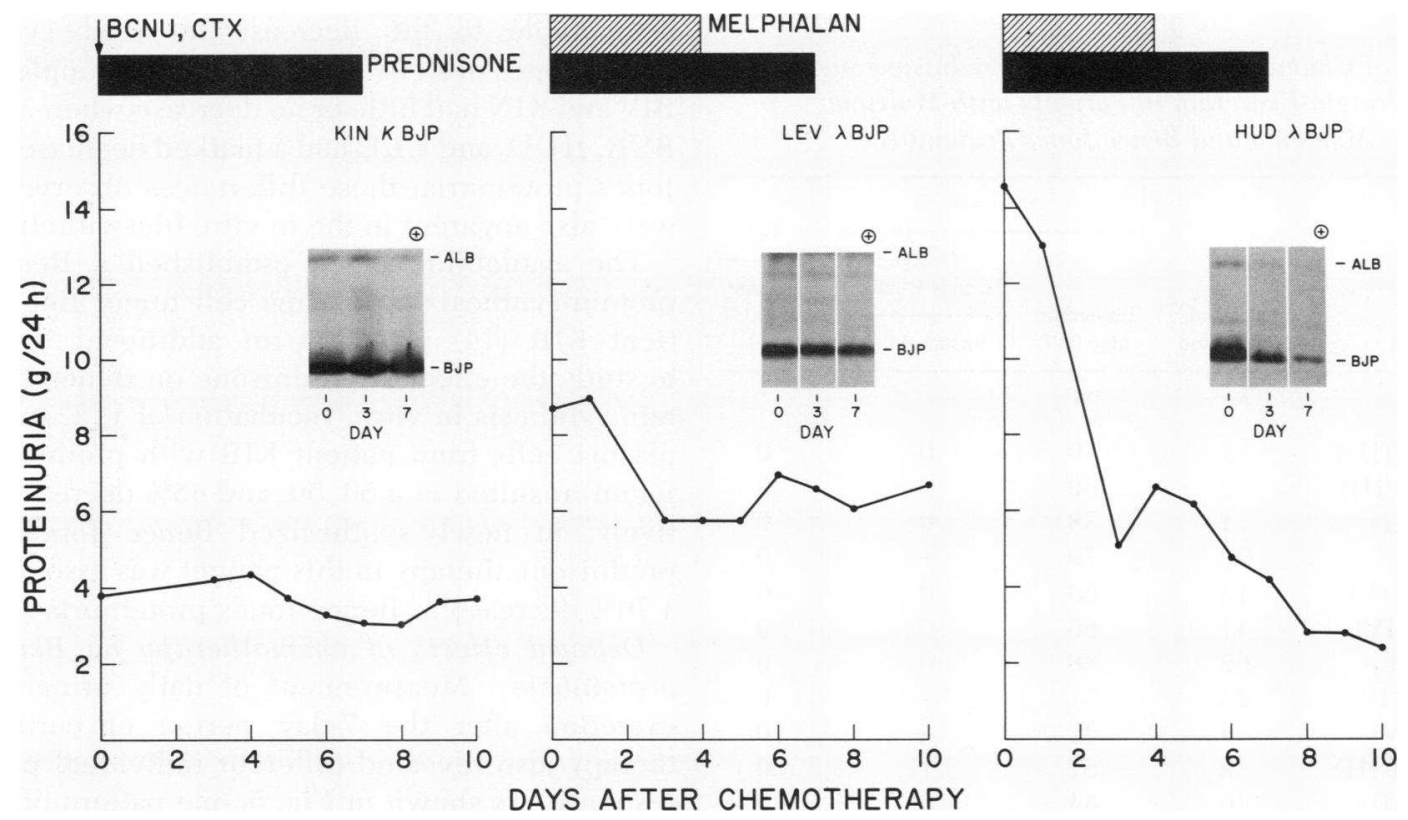

FIGURE 2 Effects of chemotherapy on urinary protein excretion in three patients with multiple myeloma and Bence Jones proteinuria. The amount of daily 24-h urinary protein excreted during a 10-day period after initiation of chemotherapy is presented graphically. The treatment schedules were as indicated in Fig. 1. In addition, the hatched bars indicate melphalan, $8 \mathrm{mg} / \mathrm{m}^{2}$, given orally for 4 consecutive days. The analyses by cellulose acetate electrophoresis of urine specimens obtained on days 0,3 , and 7 are indicated for each patient. BJP, Bence Jones protein; ALB, albumin.

the patients in this series led us to perform biosynthetic studies to determine in vitro the effect of prednisone on Bence Jones protein synthesis. Approximately $1 \times 10^{6}$ plasma cells obtained by bone marrow aspiration from patient HUD were incubated at $37^{\circ} \mathrm{C}$ with prednisone in concentrations of $15-240 \mu \mathrm{g} / \mathrm{ml}$ in a growth medium containing ${ }^{14} \mathrm{C}$-labeled lysine and isoleucine. After $18 \mathrm{~h}$ at least $85 \%$ of the cells in the untreated and prednisone-treated cultures were viable as determined by their capability to exclude trypan blue dye. Differences in the amount of ${ }^{14} \mathrm{C}$-labeled protein were apparent only in cultures which contained $>60 \mu \mathrm{g} / \mathrm{ml}$ of prednisone. The amount of labeled protein decreased progressively in cultures incubated with 60,120 , and $240 \mu \mathrm{g} / \mathrm{ml}$ of prednisone and represented 85,48 , and $40 \%$, respectively, of the proteinprecipitable radioactivity in the cultures incubated without prednisone. Gel filtration analysis of each extracellular culture fluid revealed that $\sim 80 \%$ of the labeled protein eluted from the column corresponded to the position of the unlabeled Bence Jones protein of patient HUD. Further, the electrophoretic mobility and immunochemical properties of this ${ }^{14} \mathrm{C}$-labeled protein corresponded to those of Bence Jones protein from patient HUD. The marked decrease in newlysynthesized Bence Jones protein by tumor cells incubated in the presence of prednisone was similar to that observed in vivo when patient HUD was given this agent therapeutically (see Fig. 2).

The analyses by gel filtration of culture fluids from patient COL are shown in Fig. 4. The molecular profile of ${ }^{14} \mathrm{C}$-labeled protein in the control and in the prednisone-treated (60 and $120 \mu \mathrm{g} / \mathrm{ml}$ ) cultures was similar with the major and minor peaks of radioactivity corresponding to those of the dimeric and monomeric forms, respectively, of Bence Jones protein from patient COL. In culture fluids which contained 60 and $120 \mu \mathrm{g} / \mathrm{ml}$ of prednisone, the amount of labeled Bence Jones protein was $\sim 40$ and $\sim 65 \%$, respectively, less than that of the untreated control as determined immunochemically. Gel filtration and electrophoretic analyses of extracellular culture fluids plus carrier (unlabeled) Bence Jones proteins and, where present, myeloma proteins from other patients revealed a similarity between the elution profile and electrophoretic properties of newly-synthesized protein(s) and the myeloma protein and (or) Bence Jones protein. In those patients whose serum contained either an IgG or IgA myeloma protein, $\sim 25-50 \%$ of the labeled protein represented myeloma protein and $\sim 50 \%$ represented Bence Jones protein. In such patients, the effect of prednisone on Bence Jones protein synthesis was comparable to that on myeloma protein synthesis.

The effect of prednisone on Bence Jones protein 
TABLE II

Effects of Chemotherapy Including Prednisone on Urine Protein Excretion in Patients with Multiple Myeloma and Bence Jones Proteinuria

\begin{tabular}{|c|c|c|c|c|}
\hline \multirow[b]{2}{*}{ Patient } & \multirow[b]{2}{*}{$\begin{array}{c}\text { Period of } \\
\text { observation }\end{array}$} & \multicolumn{2}{|c|}{ Decrease } & \multirow[b]{2}{*}{$\begin{array}{c}\mathrm{C}_{\mathrm{L}^{*}} \\
\begin{array}{c}\text { Present } \\
\text { on day } 7 \\
(+)\end{array}\end{array}$} \\
\hline & & $\begin{array}{c}\text { Immediate } \\
\text { (day 0-7) }\end{array}$ & $\begin{array}{c}\begin{array}{c}\text { Delayed } \\
(\text { day } 8-28)\end{array} \\
\text { Sustained (+) }\end{array}$ & \\
\hline & mo & $\%$ & & \\
\hline $\mathrm{BIV}(\lambda \mathrm{II} / \mathrm{III}) \ddagger$ & 2 & 0 & 0 & 0 \\
\hline BOS $(\lambda I I / I I I)$ & 2 & 60 & + & 0 \\
\hline BRE ( $\kappa$ III) & 1 & 38 & 0 & 0 \\
\hline BUR $(\kappa I)$ & 23 & 79 & + & 0 \\
\hline BURG ( $\lambda I V)$ & 15 & 63 & $\mathbf{0}$ & 0 \\
\hline CLAR ( $\lambda$ IV) & 11 & 60 & 0 & 0 \\
\hline CLE $(\lambda I V)$ & 62 & 88 & 0 & 0 \\
\hline COL (кIII) & 23 & 51 & + & 0 \\
\hline COT $(\lambda I V)$ & 4 & 22 & + & 0 \\
\hline $\operatorname{COX}(\lambda I I / I I I)$ & 2 & 67 & + & 0 \\
\hline $\operatorname{COXE}(\lambda I)$ & 10 & 64 & 0 & 0 \\
\hline CRO $(\kappa \mathrm{I})$ & 17 & 79 & + & 0 \\
\hline DRU $(\kappa \mathrm{I})$ & 1 & 86 & $-t$ & 0 \\
\hline EDW $(\kappa \mathbf{I})$ & 35 & 70 & 0 & + \\
\hline HAN ( $(\boldsymbol{I})$ & 1 & 0 & $-t$ & 0 \\
\hline HUD $(\lambda I)$ & 22 & 81 & + & $\mathbf{0}$ \\
\hline HUS ( $(\kappa)$ & 19 & 49 & 0 & $\mathbf{0}$ \\
\hline KIN $(\kappa \mathbf{I})$ & 56 & 16 & 0 & 0 \\
\hline $\operatorname{KIR}(\lambda I I)$ & 2 & 76 & + & 0 \\
\hline LAY $(\kappa \mathrm{II})$ & 1 & 21 & + & 0 \\
\hline LEN ( $(\kappa \mathrm{IV})$ & 34 & 0 & $-t$ & 0 \\
\hline $\operatorname{LEV}(\lambda I I)$ & 30 & 20 & 0 & 0 \\
\hline MAS $(\lambda I I / I I I)$ & 18 & 83 & 0 & 0 \\
\hline $\operatorname{MAY}(\lambda I)$ & 22 & 46 & 0 & 0 \\
\hline $\mathrm{McC}(\kappa \mathrm{III})$ & 1 & 62 & $-t$ & 0 \\
\hline OAK (кIII) & 6 & 86 & $-t$ & + \\
\hline PAT $(\kappa \mathrm{II})$ & 29 & 37 & $-t$ & 0 \\
\hline SHE $(\lambda I)$ & 2 & 70 & 0 & 0 \\
\hline WMS $(\kappa \mathrm{I})$ & 11 & 90 & 0 & + \\
\hline
\end{tabular}

$\uparrow$ Patient died before completion of the first treatment cycle. $\$$ ( ), Immunochemical type of Bence Jones protein.

synthesis in vitro was studied in a total of 13 patients utilizing bone marrow-derived plasma cells obtained just before the initial course of chemotherapy. Differences in the amount of newly-synthesized $\left({ }^{14} \mathrm{C}\right.$ labeled) protein in extracellular fluids were not related to cell viability, but rather to the number of plasma cells cultured. As determined by radioimmunoprecipitation, the amount of ${ }^{14} \mathrm{C}$-labeled Bence Jones protein secreted into the medium by tumor cells incubated in the presence of prednisone was compared to that secreted in cultures lacking prednisone. In general, the maximum decrease in labeled protein occurred in cultures containing prednisone at a concentration of $120 \mu \mathrm{g} / \mathrm{ml}$. The percent decrease in Bence Jones proteinuria after 7 days of prednisone treatment was comparable to the decrease in newly-synthesized Bence Jones protein (Table III). For example, patients BIV and KIN had little or no decrease whereas patients BUR, HUD, and CLE had a marked decrease in Bence Jones proteinuria; these differences observed in vivo were also apparent in the in vitro biosynthetic studies.

The availability of an established $\lambda$ Bence Jones protein-synthesizing plasma cell tumor line from patient KIR (14) provided an additional opportunity to study the effect of prednisone on Bence Jones protein synthesis in vitro. Incubation of 1,2 , and $3 \times 10^{7}$ plasma cells from patient KIR with prednisone (120 $\mu \mathrm{g} / \mathrm{ml}$ ) resulted in a 50,50 , and $48 \%$ decrease, respectively, in newly-synthesized Bence Jones protein; prednisone therapy in this patient was associated with a $76 \%$ decrease in Bence Jones proteinuria (Table II).

Delayed effects of chemotherapy on Bence Jones proteinuria. Measurement of daily urinary protein excretion after the 7-day period of corticosteroid therapy also revealed different individual patterns of response. As shown in Fig. 5, one pattern of response was characterized by an immediate and sustained decrease ( $>28$ days) in Bence Jones proteinuria in patients BUR ( $\kappa$-type) who received melphalan and PAT ( $\kappa$-type) who received cyclophosphamide plus $B C N U$ in addition to prednisone. In contrast, the decrease in proteinuria in patients WMS ( $\kappa$-type) and CLE ( $\lambda$-type) was transient and by 28 days had almost reached pre-treatment levels. After a second course of chemotherapy, the urinary protein excretion in patients BUR and PAT remained at low levels, whereas the response in patients WMS and CLE was again transient. Concordance between the serum and urinary concentrations of Bence Jones protein was also noted. Bence Jones proteins were no longer detectable by immunoelectrophoretic analyses of serum specimens obtained from patients WMS and CLE after 7 days of prednisone therapy; however, the post-treatment increase in Bence Jones proteinuria was associated with the reappearance of Bence Jones proteinemia. In 23 patients in whom urine collections were obtained throughout a 28-day treatment cycle, $10 \mathrm{had}$ an immediate and sustained decrease, and 13 had an immediate but transient decrease in Bence Jones proteinuria (see Table II). Again no correlation was evident between the pattern of response and the cytotoxic agent(s) given or the type or subtype of Bence Jones protein.

Formation of Bence Jones-related protein associated with corticosteroid therapy. We have found that urine specimens from a patient who had a marked decrease in Bence Jones proteinuria associated with corticosteroid therapy also contained a low molecular weight protein related to the Bence Jones protein. This protein was designated $\mathrm{C}_{\mathrm{L}}{ }^{*}$ because of its structural and antigenic correspondence to the carboxyl- 

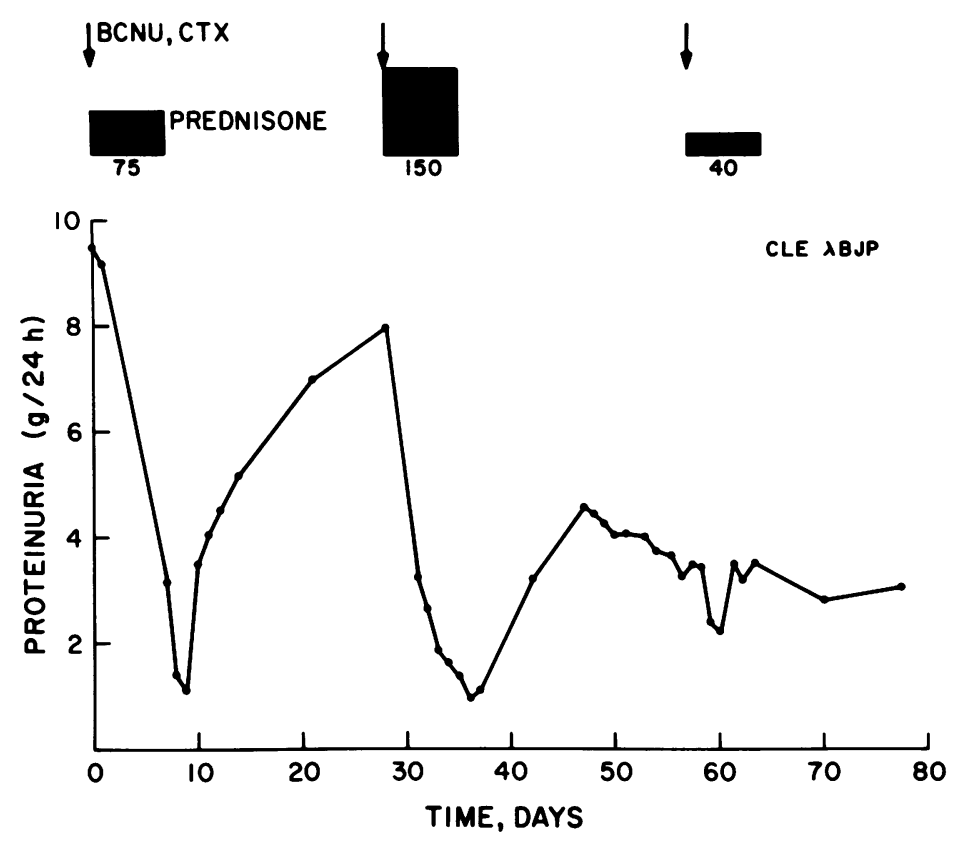

FIGURE 3 Effect of prednisone dosage on urinary protein excretion in patient CLE with multiple myeloma and Bence Jones proteinuria. The amount of daily 24-h urinary protein excreted over three 28-day treatment cycles is presented graphically. The daily $\mathrm{mg}$ dose of prednisone given for 7 days with the first, second, and third treatment cycles is indicated as 75,150 , and 40 , respectively. The treatment schedules for the cytotoxic agents were as indicated in Fig. 1. BJP, Bence Jones protein.

terminal portion, i.e., the constant $\left(\mathrm{C}_{\mathrm{L}}\right)$ region, of the Bence Jones protein polypeptide chain (8). The new protein was detectable within $72 \mathrm{~h}$ after institution of therapy, increased progressively during the additional period of corticosteroid therapy, and was no longer detectable within $24 \mathrm{~h}$ after treatment was discontinued. The $\mathrm{C}_{\mathrm{L}}{ }^{*}$ component has been identified in urine specimens from 3 of our 29 patients (Table II). In patient EDW, who had a $70 \%$ decrease in Bence Jones proteinuria during two treatment cycles, electrophoretic and immunochemical analyses of urine specimens (Fig. 6A) showed the concomitant appearance of a new com-

FIGURE 4 Effect of prednisone on biosynthesis of Bence Jones protein. Plasma cells from patient COL were incubated for $18 \mathrm{~h}$ with ${ }^{14} \mathrm{C}$-labeled amino acids (see Methods) and the profile of the newly-synthesized (labeled) protein in the extracellular culture fluids determined by gel filtration analyses. Each culture fluid plus $100 \mathrm{mg}$ of unlabeled dimeric and monomeric $\kappa$ Bence Jones protein from patient COL was applied to an Ultrogel AcA54 polyacrylamide-agarose column and eluted (see Methods). The distribution of radioactivity in the control culture $A\left(-\cdot \cdot_{-} \cdot-\right)$ and prednisone-treated cultures $B, 60 \mu \mathrm{g} / \mathrm{ml},(--)$, and $C, 120 \mu \mathrm{g} / \mathrm{ml},(\cdots)$ ) are compared; the absorbance profile $(700 \mathrm{~nm})$ of Bence Jones protein from patient COL is indicated by (-). BJP, Bence Jones protein.

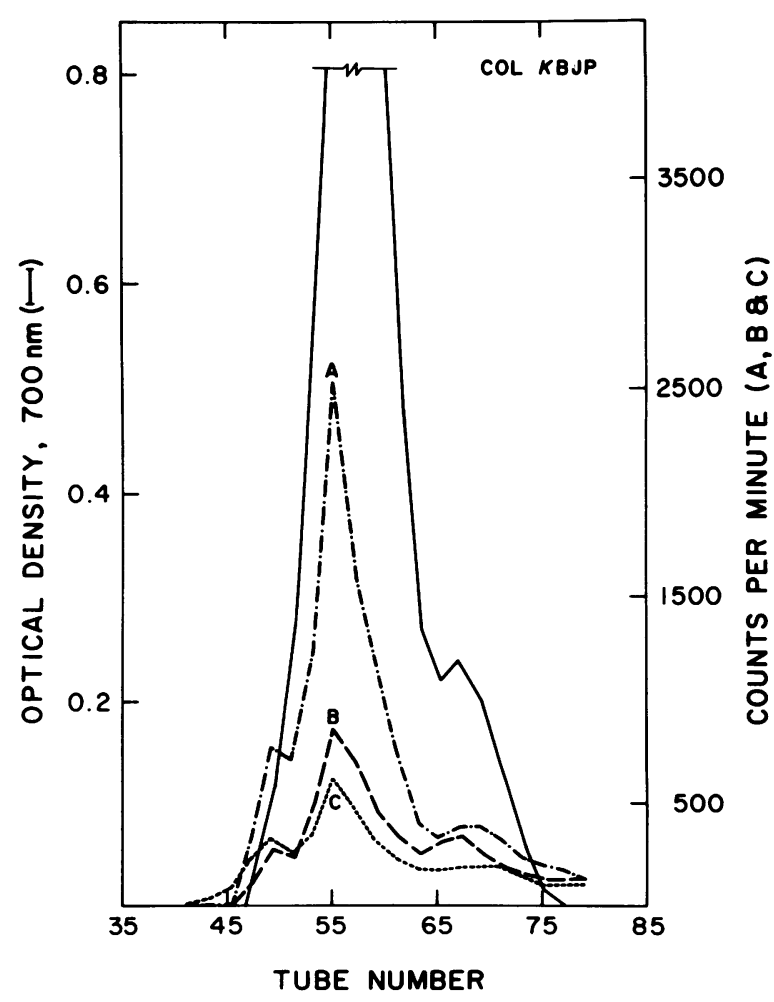


TABLE III

Comparison of the Effect of Prednisone In Vivo and In Vitro on Excretion and Synthesis of Bence Jones Protein

\begin{tabular}{|c|c|c|c|c|c|c|}
\hline \multirow[b]{2}{*}{ Patient } & \multicolumn{3}{|c|}{ Bence Jones protein excretion } & \multicolumn{3}{|c|}{ Bence Jones protein synthesis } \\
\hline & $\begin{array}{c}\text { Before } \\
\text { treatment } \\
\text { (Day 0) }\end{array}$ & $\begin{array}{c}\text { After } \\
\text { treatment } \\
\text { (Day 7) }\end{array}$ & Decrease & Control & $\begin{array}{l}\text { Prednisone } \\
(120 \mu \mathrm{g} / \mathrm{ml})\end{array}$ & Decrease \\
\hline & \multicolumn{2}{|c|}{$g / 24 h$} & $\%$ & \multicolumn{2}{|c|}{$c p m \times 0.001^{*}$} & $\%$ \\
\hline $\operatorname{BIV}(\lambda) \downarrow$ & 10.2 & 15.0 & 0 & 95 & 82 & 14 \\
\hline $\operatorname{KIN}(\kappa)$ & 3.8 & 3.2 & 16 & 327 & 290 & 11 \\
\hline $\operatorname{LEV}(\lambda)$ & 10.0 & 8.0 & 20 & 115 & 69 & 40 \\
\hline $\operatorname{COT}(\lambda)$ & 3.1 & 2.4 & 22 & 110 & 46 & 58 \\
\hline $\operatorname{PAT}(\kappa)$ & 7.6 & 4.8 & 37 & 794 & 497 & 47 \\
\hline $\operatorname{BRE}(\kappa)$ & 11.0 & 6.8 & 38 & 116 & 69 & 41 \\
\hline $\operatorname{MAY}(\lambda)$ & 17.8 & 9.7 & 46 & 508 & 188 & 63 \\
\hline $\operatorname{HUS}(\kappa)$ & 9.8 & 5.0 & 49 & 22 & 10 & 55 \\
\hline $\operatorname{COL}(\kappa)$ & 45.0 & 22.0 & 51 & 71 & 25 & 65 \\
\hline $\operatorname{BOS}(\lambda)$ & 3.0 & 1.2 & 60 & 815 & 401 & 51 \\
\hline $\operatorname{BUR}(\kappa)$ & 2.4 & 0.5 & 79 & 21 & 6 & 71 \\
\hline $\operatorname{HUD}(\lambda)$ & 3.2 & 0.6 & 81 & 16 & 3 & 81 \\
\hline $\operatorname{CLE}(\lambda)$ & 8.0 & 1.0 & 88 & 87 & 4 & 95 \\
\hline
\end{tabular}

* ${ }^{14} \mathrm{C}$-labeled protein precipitated by anti-Bence Jones protein antisera.

$\$($ ), Immunochemical type of Bence Jones protein.

ponent located cathodal to the intact Bence Jones protein. This component was detected by immunoelectrophoretic analysis 5 days after treatment was initiated (Fig. 6B); it increased in concentration by day 7 , and could not be detected $24 \mathrm{~h}$ after the course of prednisone was completed. Immunochemical analyses revealed that the component lacked antigenic determinants located on the amino-terminal portion or variant $\left(\mathrm{V}_{\mathrm{L}}\right)$ region of $\kappa$ Bence Jones protein from patient EDW, but shared antigenic determinants with heterologous $\kappa$ Bence Jones proteins. This $\mathrm{C}_{\mathrm{L}}{ }^{*}$ component was isolated from a urine specimen and the sequence of the first 11 amino acid residues was Val-Ala-Ala-Pro-Ser-Val-Phe-Ile-Phe-Pro-Pro. By homology with the sequence of $\kappa$ light chains (8), the amino-terminus of this $\mathrm{C}_{\mathrm{L}}{ }^{*}$ component corresponded to position 110 which is located adjacent to the position between the $\mathrm{V}$ and $\mathrm{C}$ regions (positions 108/109).
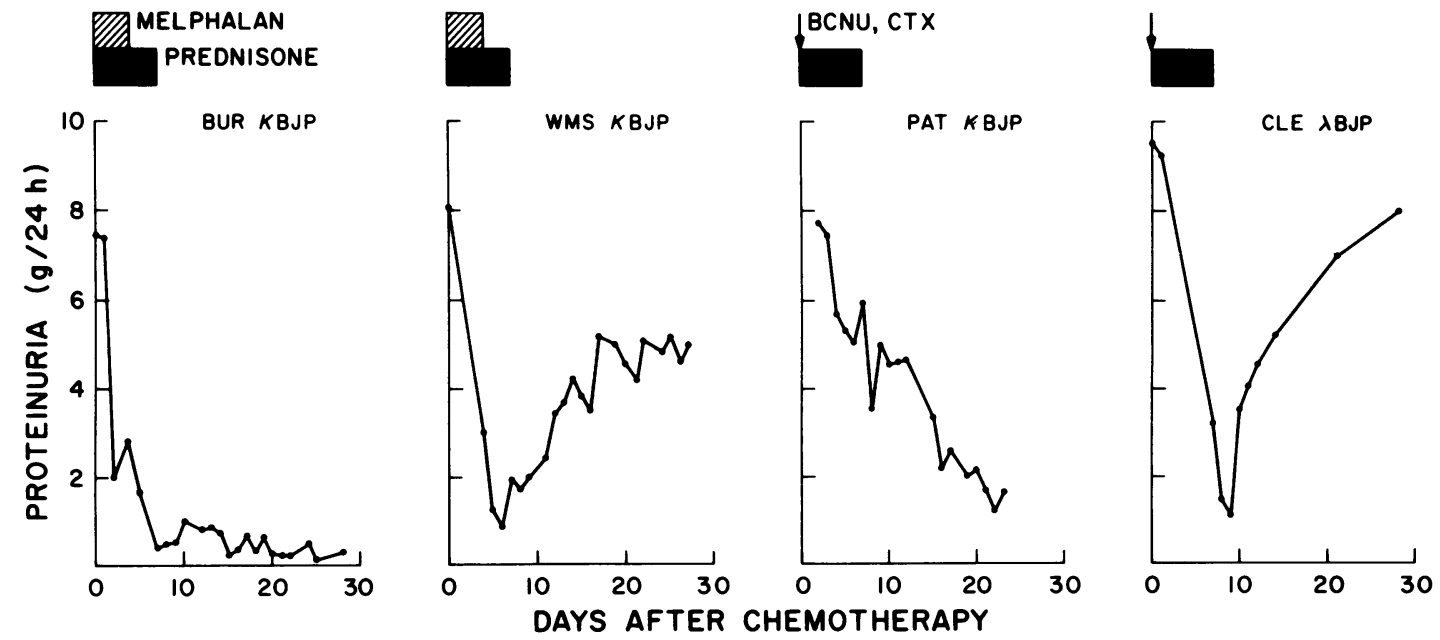

FIGURE 5 Patterns of urinary protein excretion during one treatment cycle in four patients with multiple myeloma and Bence Jones proteinuria. The amount of daily 24 -h urinary protein excreted during a 28-day period is presented graphically. The treatment schedules were as indicated in Figs. 1 and 2. BJP, Bence Jones protein. 


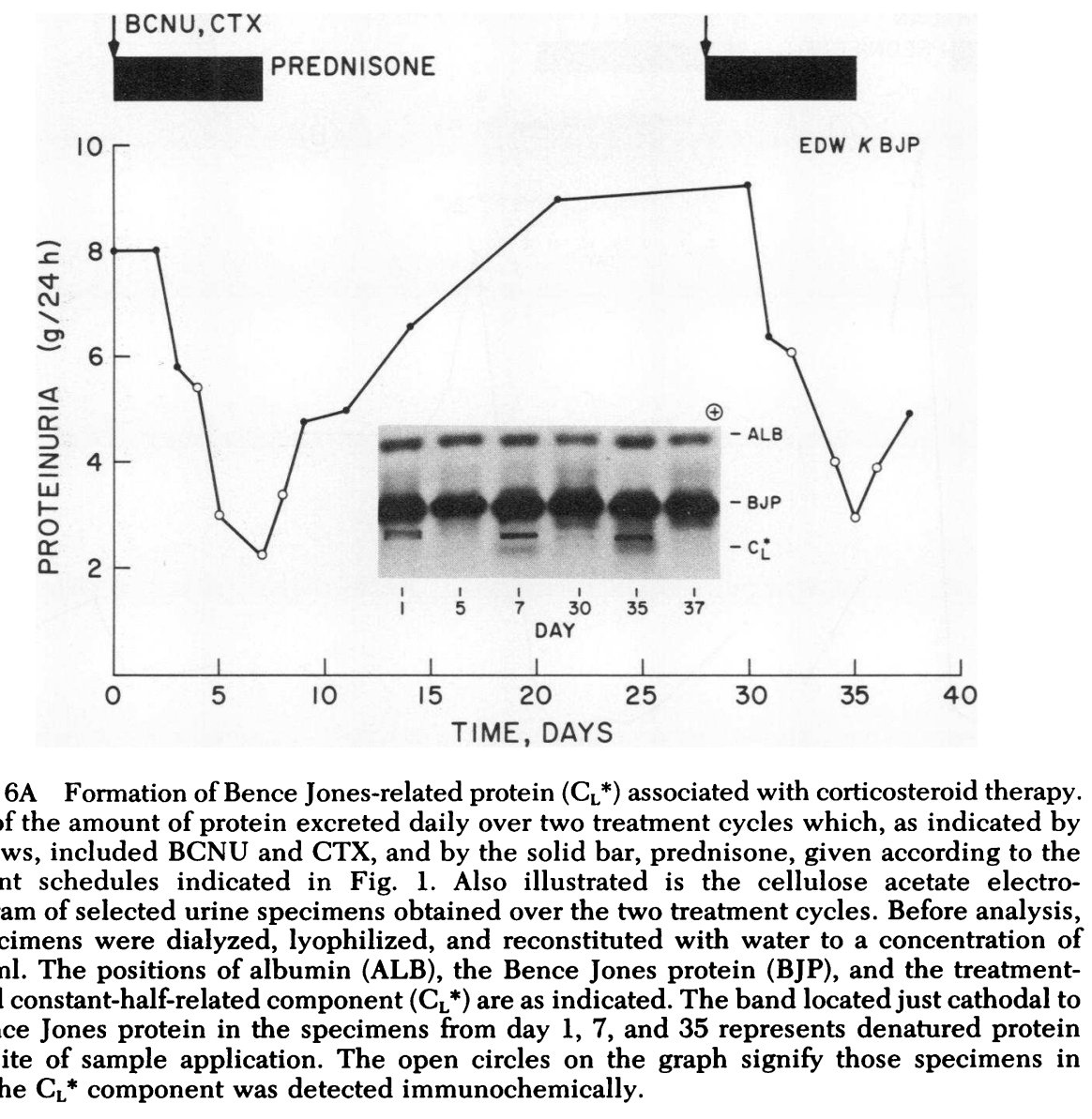

The amino-terminus of $\mathrm{C}_{\mathrm{L}}{ }^{*}$ from patient EDW differed from those of $\mathrm{C}_{\mathrm{L}}{ }^{*}$ from patients WMS and OAK which corresponded to positions 92 and $97 / 106$, respectively, of the $\kappa$ light polypeptide chain (8). ${ }^{4}$ The $\mathrm{C}_{\mathrm{L}}{ }^{*}$ components failed to precipitate when heated to $100^{\circ} \mathrm{C}$ and thus lacked the characteristic thermal properties of Bence Jones proteins. The Inv antigenicities of $\mathrm{C}_{\mathrm{L}}{ }^{*}$ from patients WMS and OAK were 16- to 32-fold less than that expressed by the intact Bence Jones proteins from patients WMS and OAK. ${ }^{5}$

Corticosteroid-induced proteinuria. 26 of the 29 patients had some decrease in urinary protein excretion during the 7-day period of corticosteroid administration. One such responsive patient, HUS, was unique in that a marked but transient increase in proteinuria occurred within 24-48 h after prednisone

\footnotetext{
${ }^{4} \mathrm{C}_{\mathrm{L}}{ }^{*}$ from patient OAK consisted of two components of approximately equal concentration; the amino-terminus of components one and two corresponded to positions 97 and 106 , respectively. The sequence analyses were performed by Dr. J. Donald Capra, University of Texas Southwestern Medical School, Dallas, Texas.

5 The Inv antigenicities were determined by Dr. Arthur G. Steinberg, Case Western Reserve University, Cleveland, Ohio.
}

was discontinued (Fig. 7). Before treatment, $\sim 70 \%$ of the urinary protein consisted of Bence Jones protein, the remainder being albumin and trace amounts of other serum proteins. A marked decrease in Bence Jones proteinuria occurred during the first 7 days of two successive 28-day treatment cycles (cycles $A$ and B). The transient increase in proteinuria from 4 to $23 \mathrm{~g}$

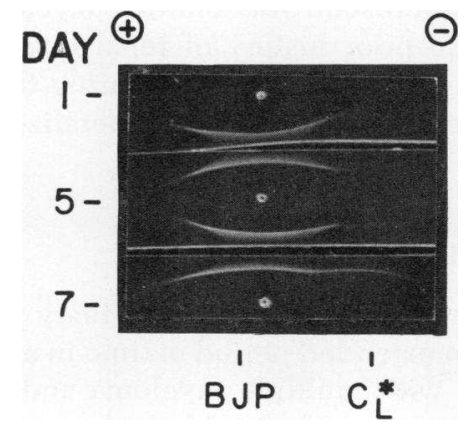

FIGURE 6B Immunoelectrophoretic analysis of urine specimens obtained during the first treatment cycle. The location of the precipitin arcs formed by the Bence Jones protein (BJP) from patient EDW and the constant-half-related component $\left(\mathrm{C}_{\mathrm{L}}{ }^{*}\right)$ are as indicated. The troughs contained an antiserum to Bence Jones protein from patient EDW. 


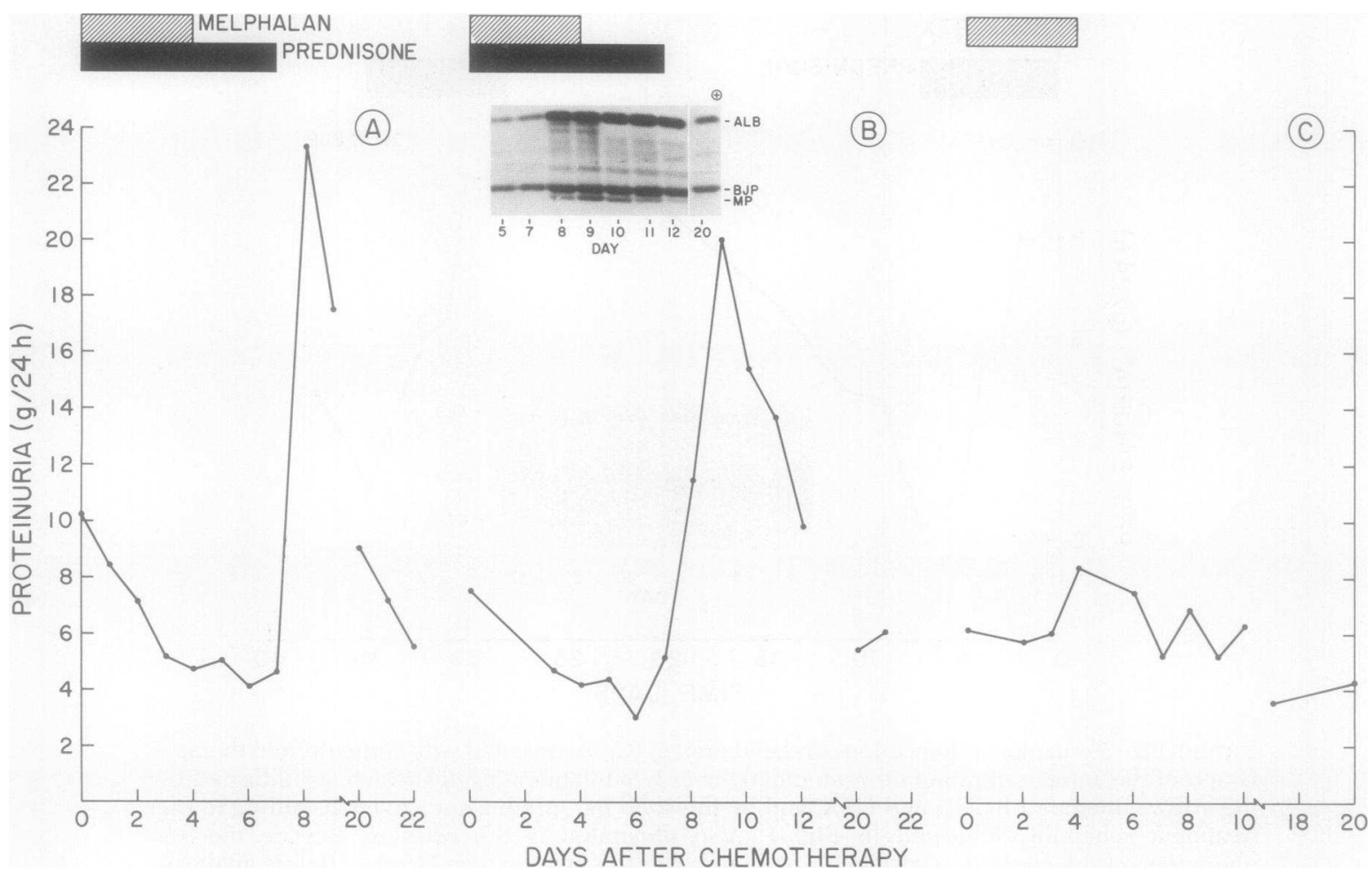

FIGURE 7 Transient posttreatment exacerbation of proteinuria associated with administration of corticosteroids to a patient with IgG $\kappa$ multiple myeloma and $\kappa$ Bence Jones proteinuria. A graph of the amount of protein excreted daily during three consecutive treatment cycles (A, B, and $C$ ) is presented. Each cycle included treatment with melphalan; prednisone was given during cycles $A$ and $B$ only (the treatment schedules were as indicated in Figs. 1 and 2). The analysis by cellulose acetate electrophoresis of urine specimens obtained during treatment cycle $B$ is presented. The positions of albumin (ALB), Bence Jones protein (BJP), and the IgG myeloma protein (MP) in the electropherogram are as indicated.

in cycle $\mathrm{A}$ and from 3 to $20 \mathrm{~g}$ in cycle $\mathrm{B}$ represented an increase not only in Bence Jones protein but in albumin and other serum protein constituents including the IgG myeloma protein. This striking postcorticosteroid "rebound" proteinuria did not occur at all when prednisone was omitted (cycle C). The patient had no prior history of renal disease nor were clinical manifestations evident during the immediate posttreatment period when the generalized proteinuria occurred.

\section{DISCUSSION}

Through measurement of daily urinary protein excretion over an extended period of time in a large number of patients with multiple myeloma and Bence Jones proteinuria, we have been able to document the effects of chemotherapy on the excretion of Bence Jones protein. The most immediate and striking changes were associated with the administration of corticosteroids given in addition to the cytotoxic agents melphalan or cyclophosphamide plus BCNU. Treatment of 29 such patients with regimens which included $75 \mathrm{mg}$ of prednisone given orally for 7 consecutive days resulted, during this period, in at least at $25 \%$ reduction of Bence Jones proteinuria in 22 individuals, 9 of whom had $>75 \%$ reduction in proteinuria as compared to pre-treatment values. This decrease can be attributed primarily to a corticosteroid effect rather than to the cytotoxic agents because of the transient nature of the response exhibited by certain patients, the temporal relationship between the response and period of hormone administration, and the lack of response when prednisone was omitted.

The amount of Bence Jones protein excreted in the urine of a patient with multiple myeloma is dependent on metabolic factors, i.e., rates of synthesis and catabolism of the protein (15-17). Further, inasmuch as Bence Jones proteins are catabolized primarily in the kidney, the relative contribution of catabolism and urinary loss to the clearance of Bence Jones protein from the blood is determined by renal function (16-19). Studies of the turnover of radioiodinated Bence Jones proteins in man have shown that the 
catabolic rate is reduced in the uremic state, whereas the proteinuric rate is increased in conditions associated with impaired glomerular or renal tubular function $(20,21)$. However, it seems unlikely that the marked decrease in Bence Jones proteinuria associated with chemotherapy resulted from an increased catabolic rate or a decreased proteinuric rate. One patient, in fact, had a remarkable increase in proteinuria that occurred transiently after 7 days of prednisone treatment (Fig. 7). This "nephrotic" type of proteinuria, observed in only 1 of our 29 patients, implies a corticosteroid-induced increase in glomerular permeability.

That corticosteroids affected the synthesis of Bence Jones proteins in certain patients was suggested by the results of biosynthetic studies. Prednisone had little effect on the amount of Bence Jones protein synthesized by plasma cells obtained from those patients in whom prednisone therapy resulted in a slight decrease in Bence Jones protein excretion. Alternatively, the maximum effect of prednisone in vitro on suppression of Bence Jones protein synthesis occurred in those patients who had the most marked corticosteroid-associated decreases in Bence Jones proteinuria.

Suppression of Bence Jones protein synthesis by corticosteroids could not be attributed to a cytotoxic effect of the hormone on plasma cells because of the transitory nature of the hormone-associated decrease in Bence Jones proteinuria plus the lack of difference in cell viability in prednisone-treated vs. control cultures. Among our patients, treatment regimens which included administration of prednisone for 7 days had a variable effect on the amount of Bence Jones protein excreted. Nevertheless, the type of response was characteristic for each patient and recurred in subsequent treatment cycles. It seems unlikely that pharmacokinetic factors (e.g., drug absorption, transport, or metabolism) could have accounted for the heterogeneity of response. The type of response appears instead to signify a variation in the capacity of corticosteroids to affect synthesis of immunoglobulin among different clones of plasma cells.

Steroid hormones, by their interaction with specific hormone-binding cytoplasmic receptor proteins, can regulate protein synthesis in hormone-responsive cells (reviewed in Ref. 22); the nuclear translocation of the hormone-receptor protein complex and its binding to nuclear chromatin apparently affects protein synthesis by controlling transcription of messenger RNA. Such receptors for glucocorticoids have been detected in normal and neoplastic corticosteroid-responsive cells (1), including murine lymphomas (23) and certain forms of human leukemias (24). ${ }^{6}$ We have found that

\footnotetext{
${ }^{6}$ A receptor protein of high affinity and specificity for the corticosteroid dexamethasone has been demonstrated in
}

plasma cells from the established $\lambda$ Bence Jones protein-synthesizing plasma cell tumor line of patient KIR (see Results) contain receptor protein of high binding affinity for dexamethasone ${ }^{7}$ it remains to be established whether the observed differences in the effect of corticosteroids on Bence Jones protein or immunoglobulin synthesis (5-7) reflect quantitative or qualitative differences in glucocorticoid-receptor proteins among clones of plasma cells. The formation of $\mathrm{C}_{\mathrm{L}}{ }^{*}$ components, noted in three patients, may signify yet another effect of the putative corticosteroid-receptor protein complex on transcription of plasma cell messenger RNA, although a catabolic origin of these proteins cannot be excluded (8). Because the concentrations of prednisone used in the biosynthetic studies were several orders of magnitude greater than that required in other systems for controlling protein synthesis via receptor complexing and transcriptional control, the corticosteroid-associated alterations of Bence Jones protein synthesis may have resulted from other known biochemical effects of corticosteroids, e.g., on lysosomal and other membranes (1).

The corticosteroid-associated effects on Bence Jones protein excretion in our patients was most often transient. The sustained decrease in Bence Jones proteinuria after a single treatment cycle or, more commonly, the gradual decrease in Bence Jones proteinuria after three to six treatment cycles was invariably associated with remission of disease and was attributed primarily to the cytotoxic agents. Corticosteroids alone have rarely been effective in treatment of multiple myeloma; but, when used adjunctively, they may enhance the benefit of cytotoxic chemotherapy and be especially useful in treating certain complications of the disease (25-27). Because of the marked abnormalities in renal function and other phenomena associated with Bence Jones proteinuria $(15,28,29)$, the ability to ascertain in vitro the effect of corticosteroids on Bence Jones protein synthesis has potential usefulness in the design of treatment protocols for patients with multiple myeloma and Bence Jones proteinuria.

\section{ACKNOWLEDGMENTS}

The author thanks Dr. J. Donald Capra for amino acid sequence analyses and Dr. Arthur G. Steinberg for Inv typing of the Bence Jones-related proteins. The constructive re-

lymphoblasts from untreated patients with acute lymphocytic leukemia. This receptor protein was not present in cells obtained from corticosteroid-resistant patients. Further, the uptake and incorporation into DNA of $\left[{ }^{3} \mathrm{H}\right]$ thymidine by leukemic cells cultured in the presence of dexamethasone correlated with the presence of the dexamethasone-binding protein in cells containing the receptor protein; no uptake or incorporation occurred in cells lacking the receptor protein (24).

${ }^{7}$ Boyd, P. A., and A. Solomon. Unpublished observations. 
views of Drs. Francis T. Kenney and Walter R. Farkas, the editorial assistance of Mses. Martha C. Childs and Martha S. Evers, and the technical assistance of Ms. Mildred Conley are gratefully acknowledged.

This investigation was supported by U. S. Public Health Service Research Grants CA 10056-12 and CA 13237-04 from the National Cancer Institute and the Stein Cancer Research Fund.

\section{REFERENCES}

1. Friedman, E. A. (editor). 1975. Proceedings of the First International Symposium on Corticosteroids as Immunosuppressive Drugs. Transplant. Proc. 7: 1-129.

2. Claman, H. N. 1972. Corticosteroids and lymphoid cells. N. Engl. J. Med. 287: 388-397.

3. Yu, D. T. Y., P. J. Clements, H. E. Paulus, J. B. Peter, J. Levy, and E. V. Barnett. 1974. Human lymphocyte subpopulations. Effect of corticosteroids. J. Clin. Invest. 53: $565-571$.

4. Fauci, A. S., D. C. Dale, and J. E. Balow. 1976. Glucocorticosteroid therapy: mechanisms of action and clinical considerations. Ann. Intern. Med. 84: 304-315.

5. Butler, W. T., and R. D. Rossen. 1973. Effects of corticosteroids on immunity in man. I. Decreased serum IgG concentration caused by 3 or 5 days of high doses of methylprednisolone. J. Clin. Invest. 52: 2629-2640.

6. Butler, W. T., R. B. Couch, R. D. Rossen, and E. M. Hersh. 1974. Methylprednisolone fails to inhibit primary and secondary antibody responses but causes marked suppression of on-going antibody formation in man. J. Clin. Invest. 53: 14a (Abstr.).

7. McMillan, R., R. Longmire, and R. Yelenosky. 1976. The effect of corticosteroids on human IgG synthesis. $J$. Immunol. 116: 1592-1595.

8. Solomon, A., C. L. McLaughlin, and J. D. Capra. 1975. Bence Jones proteins and light chains of immunoglobulins. XI. A transient Bence Jones-related protein associated with corticosteroid therapy. J. Clin. Invest. 55: 579-586.

9. Osserman, E. F., and M. Farhangi. 1972. Plasma cell myeloma. In Hematology. W. J. Williams, E. Beutler, A. J. Erslev, and R. W. Rundles, editors. McGraw-Hill, Inc., New York. 114: 956-968.

10. Solomon, A., and C. L. McLaughlin. 1973. Immunoglobulin disturbances and their clinical significance. Med. Clin. N. Am. 57: 499-516.

11. Solomon, A., and C. L. McLaughlin. 1969. Bence Jones proteins and light chains of immunoglobulins. II. Immunochemical differentiation and classification of kappachains. J. Exp. Med. 130: 1295-1311.

12. McLaughlin, C. L., and A. Solomon. 1974. Immunochemical classification of nonisolated light chains of immunoglobulins. J. Immunol. 113: 1369-1372.

13. Solomon, A., and C. L. McLaughlin. 1969. Bence-Jones proteins and light chains of immunoglobulins. I. Formation and characterization of amino-terminal (variant) and carboxyl-terminal (constant) halves. J. Biol. Chem. 244: 3393-3404
14. Lozzio, C. B., A. Solomon, B. B. Lozzio, and M. B. Klepper. 1975. Characterization of a multiple myeloma cell line of human origin. I.R.C.S. (Int. Res. Commun. Syst.) Med. Sci.-Libr. Compend. 3: 14.

15. Solomon, A. 1976. Medical Progress: Bence-Jones proteins and light chains of immunoglobulins. N. Engl. J. Med. 294: 17-23, 91-98.

16. Solomon, A., T. A. Waldmann, J. L. Fahey, and A. S. McFarlane. 1964. Metabolism of Bence Jones proteins. J. Clin. Invest. 43: 103-117.

17. Jensen, K. 1970. Metabolism of Bence Jones proteins in multiple myeloma patients and in patients with renal disease. Scand. J. Clin. Lab. Invest. 26: 13-21.

18. Wochner, R. D., W. Strober, and T. A. Waldmann. 1967. The role of the kidney in the catabolism of Bence Jones proteins and immunoglobulin fragments. J. Exp. Med. 126: 207-221.

19. Miettinen, T. A., and M. Kekki. 1967. Effect of impaired hepatic and renal function on ${ }^{131}$ I Bence Jones protein catabolism in human subjects. Clin. Chim. Acta. 18: 395-407.

20. Waldmann, T. A., W. Strober, and R. P. Mogielnicki. 1972. The renal handling of low molecular weight proteins. II. Disorders of serum protein catabolism in patients with tubular proteinuria, the nephrotic syndrome, or uremia. J. Clin. Invest. 51: 2162-2174.

21. Strober, W., and T. A. Waldmann. 1974. The role of the kidney in the metabolism of plasma proteins. Nephron. 13: $35-66$.

22. Baulieu, E. E., M. Atger, M. Best-Belpomme, P. Corvol, J. C. Courvalin, J. Mester, E. Milgrom, P. Robel, H Rochefort, and D. de Catalogne. 1975. Steroid hormone receptors. Vitam. Horm. 33: 649-736.

23. Rosenau, W., J. D. Baxter, G. G. Rousseau, and G. M. Tomkins. 1972. Mechanism of resistance to steroids: Glucocorticoid receptor defect in lymphoma cells. Nat. New Biol. 237: 20-23.

24. Lippman, M. E., R. H. Halterman, B. G. Leventhal, S. Perry, and E. B. Thompson. 1973. Glucocorticoid-binding proteins in human acute lymphoblastic leukemic blast cells. J. Clin. Invest. 52: 1715-1725.

25. Caggiano, V., J. Cuttner, and A. Solomon. 1967. Myeloma proteins, Bence Jones proteins and normal immunoglobulins in multiple myeloma. Blood. 30: 265-287.

26. Salmon, S. E., R. K. Shadduck, and A. Schilling. 1967. Intermittent high-dose prednisone (NSC-10023) therapy for multiple myeloma. Cancer Chemother. Rep. 51: 179-187.

27. Hoogstraten, B. 1973. Steroid therapy of multiple myeloma and macroglobulinemia. Med. Clin. N. Am. 57: $1321-1330$.

28. Solomon, A., and J. L. Fahey. 1964. Bence Jones proteinemia. Am. J. Med. 37: 206-222.

29. Josephson, A. S., M. V. Bake, and M. R. Murali. 1975. A possible mutational event in multiple myeloma and reversal of Bence Jones proteinuria and renal failure by steroid therapy. Clin. Res. 23: 584A (Abstr.). 